\title{
Reflecting Patterns of Strategic Thinking on Organizational Conflict - The Search a Comparative Analysis
}

\author{
Ahmed Quinn Dawood ${ }^{1}$, Dr. Suheir Adel AL-Jader ${ }^{2}$ \\ ${ }^{1}$ Department of Public Administration, College of Administration and Economics, University of Baghdad, Iraq \\ Jeweler987k3[at]gmail.com \\ ${ }^{2}$ Department of Public Administration, College of Administration and Economics, University of Baghdad, Iraq
}

\begin{abstract}
This research aims To study the reflection of strategic thinking patterns, The patterns of b (Concrete Synthesis pattern, concrete analysis pattern, Synthesis pattern, abstract analysis pattern, abstract Synthesis pattern), On organizational conflict represented by (conflict at the individual level, the conflict on the group level, the conflict on the organization level), The Ministry of Education and the Ministry of Higher Education and Scientific Research have approved to act as a study site, The Comparative analytical approach was used in completing this research, And it also used the questionnaire as a tool in data and information related to research collection, And distributed to a sample of (118) personnel distributed in the post (department manager) as well as the use of interviews to strengthen the answers to the questionnaire, The researcher used the correlation coefficient (Spearman) and regression analysis to analyze relationships and test hypothesis.
\end{abstract}

Keywords: patterns of strategic thinking, organizational conflict

\section{Introduction}

Business organizations seek to look towards the future, with the aim of achieving their goals, Through the use of strategic thinking methods to diagnose potential opportunities and threats and to confront and manage organizational conflicts at various levels and to introduce new alternatives and make successful decisions, Strategic thinking is considered to be detrimental to the requirements of economic growth, development, social development, scientific progress, technological excellence, entrepreneurship, conflict and challenges, The main objectives of the study of the reality of any organization working in the field of services, By focusing on how well principals exercise strategic thinking within the organization, As they practice strategic thinking.

On the other hand, organizations do not abandon organizational conflicts, At various levels of organizational conflicts, So the problem lies in how individuals and managers employ strategic thinking patterns to confront those conflicts to make them within a moderate and acceptable level, Research and studies suggest that these conflicts can be positive and constructive, Based on this importance of strategic thinking patterns and dealing with the organizational conflict, This research was conducted to identify the nature of the relationship of correlation and influence between the variables of both types of strategic thinking and levels of organizational conflict.

\section{Literature Review}

\subsection{Strategic thinking}

Strategic thinking as a process that involves collection, combination and filtration of information to generate new, relevant, focused and feasible ideas and strategies (1). Strategic thinking is nothing new. As early as 2, 500 years ago, noted Chinese strategist Sun Tzu discussed the concept of strategic thinking: "Warfare is the greatest affair of state....It must be thoroughly pondered and analyzed" (2). Sun Tzu further clarified this thinking to include the evaluation of comparative estimations and the need to seek out the true nature of the war ${ }^{(3)}$.

Military strategic thinking flourished during the Enlightenment, culminating in the Napoleonic (1990 1815) era of advanced strategic and tactical developments (4).

Then it is considered any discussion of modern strategy thinking should begin with a review of the work of the Prussian General Carl von Clausewitz (1780-1831). Who is widely regarded as the first modern strategist thinking. His monumental study On War (published in 1832) is considered the definitive work in the field; It covers a wide range of subjects, from the philosophical to the minutely practical ${ }^{(5)}$.

In the mid-20th century, specifically in 1950, The search for strategic thinkers for their employment within the organization has increased To achieve sustainable competitive development through increased operational plans of organizations, increased competition, market access, product excellence, etc ${ }^{(6)}$.

At the turn of the twentieth century it contributed, three management scholars would probably top the list: Igor Ansoff, Peter Drucker, and Michael Porter. They represent three schools of thought and three periods of time (with a measure of overlap here and there). Ansoff's pioneering work on corporate strategy dates back to the 1960s and represented, at that point in time, the nearest thing to a

\section{Volume 6 Issue 12, December 2017}

\section{www.ijsr.net}




\section{International Journal of Science and Research (IJSR) \\ ISSN (Online): 2319-7064}

Index Copernicus Value (2015): 78.96 | Impact Factor (2015): 6.391

breakthrough. Drucker's work The Practice of Management first appeared in the mid-1950s and introduced a collection of fresh insights into the workings of corporate management. Porter's work on competitive strategy first appeared in 1980 and constituted a landmark in terms of strategic thinking within a competitive environment. All three were heroes of their time. They provided bright and innovative conceptual frameworks that addressed core management issues of the era and established their viability. Their legacy continued for decades. They crossed time horizons, regime change, and environmental turmoil. They penetrated functional walls, management strata, and geographical barriers ${ }^{(7)}$.

Given the interconnected nature of today's environment rife with unpredictable events, senior leaders and staffs must be capable of strategic thinking. The relationship between leader and staff is symbiotic, and supporting staffs must think strategically to provide the appropriate support to their senior leaders ${ }^{(3)}$.

\section{- Patterns of strategic thinking model}

Suggested (Stamp) model patterns of strategic thinking in 1981, Considering there are five distinct patterns of thinking of each manager, And then touched (Stamp) to that model year (1986) and held several additions, He proposed a format through which these five patterns could be distributed on two axes, And share each with some two patterns and constitute a double pattern, A single independent pattern mediates the four common patterns, And to clarify more through Figure (1).

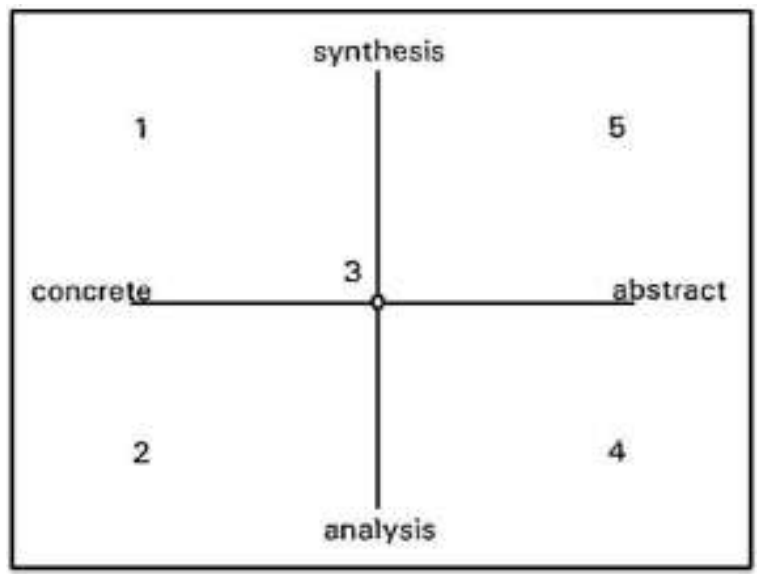

Figure 1: Model (Stamp) patterns of strategic thinking

The Stamp model includes the following types:

1. Concrete Synthesis: In this view of the world, everything is related to everything else, although action is focused firmly on one thing at a time ${ }^{(8)}$. All knowledge is experiential and comes directly from "touch and feel" contact with the world. Within this level there is only one fully-fledged way of acting which is pragmatic and intuitive. The person who prefers it could be called a proceduralist. S/he likes to work directly with external reality, building up an implicit sense of what is happening by focusing on the particular task of the moment ${ }^{(9)}$.
2. Concrete - Analysis: The individual within this level is distinguished Immersed in the awareness of living experiences, progress to reflection upon the significance of experiences and the appropriateness of the related behavior of significant persons (primarily one's self). And thought then becomes more detached and abstract during individual searching for theories which help to explain behavior in specific circumstances ${ }^{(10)}$.

3. Synthesis: In general terms the approach at this level is based in extrapolation. This produces options and creates alternatives over an extended time scale but within a closed system (11). The unknown is therefore only temporarily unknown; it is waiting to be placed in a system which will complete the structure of which the general plan was known in advance. All is continuity, each piece fits with what preceded and succeeds it, each is a link in the chain and there is an assumption of connection even if the particular links are unclear ${ }^{(\mathbf{1 2})}$.

4. Abstract analysis: In general terms, Individuals within this level are interested in the principles on which the organization is built and seek answers to the "why's" of events. They have the ability to see relationships among various departments of the company and make sense out of the activities that occur in the system ${ }^{(\mathbf{1 3})}$

5. Abstract Synthesis: From this point of view, the individual progresses continuously through a stage until the next stage is entered ${ }^{(14)}$. Entering this next stage would involve the reorganization of existing mental content, with the emergence of a relatively new structure; Fundamental among the changes which might be expected would be a different level of abstraction in thinking, and an ability to tolerate uncertainty over a longer period ${ }^{(15)}$.

\subsection{Organization Conflict}

Conflict occurs when one "party perceives that its interests are being opposed or negatively affected by another party"(16). There are three theories regarding the historical view of the concept of organizational conflict: Traditional view, interactive view, and Contemporary and modern view. The traditional approach to conflict assumed all conflict was bad and to be avoided. Conflict was viewed negatively and discussed with such terms as violence, destruction, and irrationality to reinforce its negative connotation ${ }^{(17)}$. This traditional view of conflict was consistent with attitudes about group behavior that prevailed in the $1930 \mathrm{~s}$ and $1940 \mathrm{~s}$. Conflict was a dysfunctional outcome resulting from poor communication, a lack of openness and trust between people, and the failure of managers to be responsive to the needs and aspirations of their employees ${ }^{(18)}$.

In contrast to the negative view of conflict listed above, Indicate interactive view to conflict may be constructive under certain conditions Indeed, some 50 years ago, Coser (1956) to suggest that conflict may serve a useful purpose by establishing and maintaining the identity and boundaries of the parties involved. Conflict (with out-groups) increases in-group cohesion, establishes and maintains

\section{Volume 6 Issue 12, December 2017}




\section{International Journal of Science and Research (IJSR) \\ ISSN (Online): 2319-7064}

Index Copernicus Value (2015): 78.96 | Impact Factor (2015): 6.391

power-balances, and creates allies and coalitions ${ }^{(19)}$.

Finally, recent research argues that instead of encouraging "good" or discouraging "bad" conflict, it's more important to resolve naturally occurring conflicts productively ${ }^{(20)}$. The results of the studies showed that the interest in finding a solution to the problems is based on a moderate level of conflict, The conflict is not positive and constructive, being low or high above the satisfactory level of the conflict (21).

\section{- Levels of organizational conflict}

The levels are single level, the level is the degree and status at which the object is settled, Levels of organizational conflict include three levels:

1. Intrapersonal conflict: Intrapersonal conflict happens within an individual. The conflict arises because of a threat to the person's basic values, because of a feeling of unfair treatment by the organization, or from multiple and contradictory sources of socialization (22). Intrapersonal conflict occurs within an individual and often involves some form of goal or cognitive conflict, Goal conflict occurs when a person's behavior will result in outcomes that are mutually exclusive or have incompatible elements (both positive and negative outcomes), Thus intrapersonal goal conflict involves an interplay of positive outcomes, negative outcomes, or both ${ }^{(23)}$.

2. Intergroup conflict: Intergroup conflict that occurs among members of different teams or groups can also have substantive and/or emotional underpinnings. Intergroup conflict is quite common in organizations, and it can make the coordination and integration of task activities very difficult (24).

3. Organizational conflict: is conflict between employees and the organization itself. Organizational conflict pits employees or groups of employees against the organization. Changes in policies that negatively affect employees, such as a cutback in benefits offered, are one source of organizational conflict. Reorganizations, corporate downsizing, layoff of employees, and tightening of expenses are other examples of sources of organizational conflict ${ }^{(25)}$.

The literature (e.g. Bonn, 2005; O’Shannassy, 2000) has emphasized that to study strategic thinking processes in organizations, three levels must be addressed conflict. These levels include strategic thinking at the individual level, which is explained in terms of diversity in representational systems; second, strategic thinking at group level, which looks at heterogeneity and conflict; and finally, strategic thinking within an organizational context, which seeks to examine middle management involvement in the strategic thinking process through understanding the important characteristics which influence the organizational context (i.e. organizational culture, organizational structure, reward and compensation system) (26).

\section{Research Methodology}

\subsection{Search problem}

Contemporary organizations seek to develop strategic thinking patterns among their members, It is the most important source of renewed development, In order to develop the strategic thinking patterns of its members, the organizations tended to adopt and study in depth how to develop strategic thinking within the organization, The problem of research lies in the use of strategic thinking patterns to control the levels of organizational conflict at a moderate and acceptable level, For the purpose of supporting decisions and achieving goals, Reducing the opposition of individuals to accomplish tasks and wasting money and time, Resulting from organizational conflicts.

\subsection{Research Hypotheses}

Based on the research problem The research model seeks to control the organizational conflict at various levels, Through the acquisition and development of strategic thinking patterns among managers and members of the organization, And the model contains five basic hypotheses are as follows:

H 1: There is a significant correlation relationship between the Patterns of strategic thinking (Concrete Synthesis, concrete analysis, Synthesis, abstract analysis, abstract Synthesis) and the axis of levels of organizational conflict.

H 2: There is a significant impact relationship to the Patterns of strategic thinking (Concrete Synthesis, concrete analysis, Synthesis, abstract analysis, abstract Synthesis) and the axis of levels of organizational conflict.

\subsection{The Research community}

The Research community included department managers only for the Ministry of Education and the Ministry of Higher Education and Scientific Research, The sample of the study included a stratified Intentional, The total sample of the study (118) individuals, where the number of males (81) and the number of females (37).

\subsection{Measurement}

The researchers adopted the questionnaire as one of the means of completing the research as the main source for obtaining the data and information related to the practical part of the research and then organizing the questionnaires in specific axes, which included two main axes:

the Patterns of strategic thinking as an independent variable which included five Patterns (Concrete Synthesis, concrete analysis, Synthesis, abstract analysis, abstract Synthesis) and adoption the levels of organizational conflict as a dependent variable which includes three levels (Intrapersonal conflict, Intergroup conflict, organizational conflict), Table (1) shows the number paragraphs of questionnaires and approved sources that were used to 


\section{International Journal of Science and Research (IJSR) \\ ISSN (Online): 2319-7064}

Index Copernicus Value (2015): 78.96 | Impact Factor (2015): 6.391

build the paragraphs of this questionnaire, and The questionnaire was presented to 30 Professor Dr. Professor of the owners of jurisdiction, And achieved an apparent sincerity of $94.5 \%$, An excellent ratio, Indicates the acceptance and consent of the competent authorities, and The alpha-cronbach coefficient was calculated for each axis of the questionnaire, and Table (2) shows the results, if The results achieved an excellent percentage with a high degree of dependence on the results of the questionnaire g This study and subsequent future studies, and the laboratories are reassuring confirm the validity of the scale and validity of the application.

Table 1: Variables, sub Variable, the number of paragraphs, their numbers in the questionnaire, the source adopted in the scale

\begin{tabular}{|c|c|c|c|}
\hline \multirow{2}{*}{ Variables } & Sub variable & $\begin{array}{c}\text { No of } \\
\text { items }\end{array}$ & \multirow{2}{*}{ Source } \\
\hline \multirow{4}{*}{$\begin{array}{c}\text { strategic } \\
\text { thinking } \\
\text { patterns }\end{array}$} & Concrete Synthesis & 5 & \\
\cline { 2 - 3 } & Concrete Analysis & 5 & \multirow{4}{*}{ Al-Jabri } \\
\cline { 2 - 3 } & Synthesis & 5 & 2016 \\
\cline { 2 - 3 } & Abstract analysis & 5 & \\
\cline { 2 - 3 } $\begin{array}{c}\text { levels of } \\
\text { organizational } \\
\text { conflict }\end{array}$ & Abstract Synthesis & 5 & \\
\cline { 2 - 3 } & Intrapersonal conflict & 6 & \multirow{2}{*}{$\begin{array}{c}\text { The } \\
\text { Intergroup conflict }\end{array}$} \\
\cline { 2 - 3 } & organizational conflict & 6 & 2017 \\
\hline
\end{tabular}

Table 2: The value of the stability coefficient (alphacronbach)

\begin{tabular}{|c|c|}
\hline The Questionnaire Axes & $\begin{array}{c}\text { value alpha- } \\
\text { cronbach }\end{array}$ \\
\hline Axis strategic thinking patterns & 0.93 \\
\hline Axis levels of organizational conflict & 0.83 \\
\hline
\end{tabular}

\section{Test Mann-Whitney}

The results indicated in Table No (3), To the absence of statistically significant differences between the averages of strategic thinking patterns and the average levels of organizational conflict, For the sample of the Ministry of Education and the Ministry of Higher Education and Scientific Research, Since the value of significance (Sig), For all main and sub variables are greater than (0.05). Thus, the sample results will be analyzed in a single group, without a comparison between the samples of the two ministries, Similar to the views of the sample of the two ministries.

Table 3: Results Test Mann-Whitney

\begin{tabular}{|c|c|c|c|}
\hline $\begin{array}{c}\text { Variables \& Sub } \\
\text { variable }\end{array}$ & $\begin{array}{c}\text { The test } \\
\text { value of } \\
\text { Mann- } \\
\text { Whitney }\end{array}$ & $\begin{array}{c}\text { Moral } \\
\text { value } \\
\text { (Sig.) }\end{array}$ & the decision \\
\hline $\begin{array}{c}\text { strategic thinking } \\
\text { patterns }\end{array}$ & 1521.000 & 0.416 & Not significant \\
\hline Concrete Synthesis & 1523.000 & 0.422 & Not significant \\
\hline Concrete Analysis & 1362.000 & 0.090 & Not significant \\
\hline Synthesis & 1574.000 & 0.601 & Not significant \\
\hline Abstract analysis & 1485.500 & 0.313 & Not significant \\
\hline Abstract Synthesis & 1598.000 & 0.155 & Not significant \\
\hline $\begin{array}{c}\text { levels of } \\
\text { organizational } \\
\text { conflict }\end{array}$ & 1582.500 & 0.635 & Not significant \\
\hline \multicolumn{2}{|c|}{} & &
\end{tabular}

\begin{tabular}{|l|c|c|c|}
\hline Intrapersonal conflict & 1329.500 & 0.062 & Not significant \\
\hline Intergroup conflict & 1403.000 & 0.144 & Not significant \\
\hline organizational conflict & 1634.000 & 0.848 & Not significant \\
\hline
\end{tabular}

\section{Data Analysis}

The results of the analysis of the responses, The respondents enjoy the practice of strategic thinking patterns, Overall for all patterns, And that the pattern (Concrete Analysis) and pattern (Concrete Synthesis) are the dominant members of the sample in practice at work, Indicating that the respondents have strategic thinking, And have the ability to contain the conflict within the moderate level. As results show, There is a moderate organizational conflict of various levels, the moderate level of organizational conflict is limited to (2.5 - 3.5). This shows that the two ministries, Have a positive level of work performance and achievement of goals. The results of the std. deviation are also shown, to the low dispersion of the responses in the opinion of the sample members. it shows Table (4) mean and standard deviation of Variables and Sub variables.

Table 4: shows the results of the statistical analysis of sample responses

\begin{tabular}{|c|c|c|}
\hline Variables \& Sub variable & Mean & $\begin{array}{c}\text { Std. } \\
\text { deviation }\end{array}$ \\
\hline strategic thinking patterns & $\mathbf{3 . 0 0 2}$ & $\mathbf{0 . 0 1}$ \\
\hline Concrete Synthesis & 3.07 & 0.93 \\
\hline Concrete Analysis & 3.25 & 0.65 \\
\hline Synthesis & 2.80 & 0.62 \\
\hline Abstract analysis & 2.93 & 0.61 \\
\hline Abstract Synthesis & 2.97 & 0.89 \\
\hline levels of organizational conflict & $\mathbf{2 . 8 2}$ & $\mathbf{0 . 6 5}$ \\
\hline Intrapersonal conflict & 3.38 & 0.73 \\
\hline Intergroup conflict & 2.89 & 0.92 \\
\hline organizational conflict & 3.03 & 0.59 \\
\hline
\end{tabular}

\section{Results}

\subsection{Correlations of variables}

The results shown in Table (5) That the value of the Spearman correlation coefficient between all Strategic thinking patterns (variable $\mathrm{Y}$ ) with the axis of organizational conflict levels(variable $\mathrm{x}$ ), Had a negative value with a statistical function at a significant level (0.05), Since the absolute value of $(\mathrm{T})$ is greater than its tabular counterpart (1.972), The value of $\mathrm{T}$ (table) at a significant level $(0.05)$ and the degree of freedom $(116)=1.972$, This finding means that whenever there is an obligation to apply the strategic thinking pattern by the managers under consideration, Will reduce the level of organizational conflict in the future. Thus, the hypotheses of the correlation of all types of strategic thinking will be accepted in the levels of organizational conflict. 


\section{International Journal of Science and Research (IJSR) \\ ISSN (Online): 2319-7064}

Index Copernicus Value (2015): 78.96 | Impact Factor (2015): 6.391

Table 5: Results of the correlation of strategic thinking patterns with the axis of levels of organizational conflict

\begin{tabular}{|c|c|c|c|}
\hline $\begin{array}{l}\text { Organizational } \\
\text { conflict levels/ } \\
\text { variable } \\
\text { ( x) }\end{array}$ & $\begin{array}{c}\text { Strategic } \\
\text { thinking } \\
\text { patterns/variable } \\
(\mathrm{Y})\end{array}$ & $\begin{array}{l}\text { Spearman's } \\
\text { correlation } \\
\text { coefficient } \\
(r) \\
\end{array}$ & $\begin{array}{l}\text { Value }(\mathrm{T}) \\
\text { calculated }\end{array}$ \\
\hline \multirow{5}{*}{$\begin{array}{c}\text { levels of } \\
\text { organizational } \\
\text { conflict }\end{array}$} & $\begin{array}{l}\text { Concrete } \\
\text { Synthesis }\end{array}$ & $0.263-* *$ & $2.935-$ \\
\hline & $\begin{array}{l}\text { Concrete } \\
\text { Analysis }\end{array}$ & $0.509-* *$ & $6.368-$ \\
\hline & Synthesis & $0.326-* *$ & $3.714-$ \\
\hline & $\begin{array}{l}\text { Abstract } \\
\text { analysis }\end{array}$ & $0.367-* *$ & $4.249-$ \\
\hline & $\begin{array}{c}\text { Abstract } \\
\text { Synthesis }\end{array}$ & $0.628-* *$ & 8.691- \\
\hline
\end{tabular}

\subsection{The regression of variables}

The results of the statistical analysis according to Table (6) Effect of statistical significance at a significant level (0.05) For all types of strategic thinking at the center of organizational conflict levels, And that the value of $(\mathrm{F})$ table at the degree of freedom $(1,116)$ and the level of significance $(0.05)=5.15$, Thus, the calculated value $(F)$ of all the strategic thinking patterns is greater than the scale equation (5.15), As the table shows, The increase in the (Concrete Synthesis pattern) by one unit will be accompanied by a decrease and decrease in the axis of organizational conflict levels by $27 \%$ and vice versa, The increase in (Concrete Analysis pattern) by one unit will be accompanied by a decrease and decline in the axis of levels of organizational conflict by $(50 \%)$ and vice versa, The increase in the (Synthesis pattern) by one unit will be accompanied by a decrease and decrease in the axis of organizational conflict levels by $37 \%$ and vice versa, The increase in the (Abstract analysis pattern) by one unit will be accompanied by a decrease and decline in the axis of the levels of organizational conflict by $34 \%$ and vice versa, Finally, the increase in the (Abstract Synthesis pattern) by one unit will be accompanied by a decrease and decline in the axis of levels of organizational conflict by $66 \%$ and vice versa, The five hypotheses adopted for this study will be adopted, Because of the correlation and impact of all types of strategic thinking at the center of organizational conflict levels.

Table 6: Results of the regression of variables

\begin{tabular}{|c|c|c|c|c|c|}
\hline \multirow{2}{*}{$\begin{array}{c}\text { organizational conflict } \\
\text { levels/ } \\
\text { variable } \\
(\mathrm{x})\end{array}$} & $\begin{array}{c}\text { Strategic thinking } \\
\text { patterns/variable (Y) }\end{array}$ & $\begin{array}{c}\text { Fixed limit } \\
\mathrm{A}\end{array}$ & $\begin{array}{c}\text { Regression } \\
\text { parameter } \\
\text { Beta }\end{array}$ & $\begin{array}{c}\text { Value (F) } \\
\text { calculated }\end{array}$ & $\begin{array}{c}\text { Selection factor } \\
(\mathrm{R} 2)\end{array}$ \\
\hline \multirow{3}{*}{$\begin{array}{c}\text { levels of organizational } \\
\text { conflict }\end{array}$} & Concrete Synthesis & 4.20 & $0.27-$ & 9.28 & 0.07 \\
\cline { 2 - 6 } & Concrete Analysis & 4.29 & $0.50-$ & 40.50 & 0.26 \\
\cline { 2 - 6 } & Synthesis & 4.61 & $0.37-$ & 18.34 & 0.14 \\
\cline { 2 - 6 } & Abstract analysis & 4.59 & $0.34-$ & 9.47 & 0.12 \\
\hline
\end{tabular}

\section{Conclusions}

The statistical analysis showed a number of conclusions, most notably There are no statistically and morally significant differences between the computational domains of each of the strategic thinking patterns (and in all patterns), And levels of organizational conflict (at all levels) of the sample of the Ministry of Education and the Ministry of Higher Education and Scientific Research, The results of the analysis were also shown the existence of an inverse relationship between each type of strategic thinking with the levels of organizational conflict, And that the height of each exercise pattern leads to a decline in the levels of organizational conflict, The most prominent recommendations were the development of strategic thinking patterns among department managers, And the establishment of courses on strategic thinking at five levels and stages, as it deals with Training of department managers In each style level of strategic thinking patterns and then move To their training On the second style until department managers are trained for the organizations surveyed on all five types. It also reflects on the establishment of courses in the process of empowering managers and members of the organizations in how to deal with the organizational conflict as a proactive step in the case of the rise and aggravation of the moderate level.

\section{References}

[1] Kazmi. Zenab." Fusing Strategic Thinking and Transformational Leadership to Harness New Product Development (NPD) Team Dynamics for Innovation", Published by University of Vaasa Faculty of Technology of Industrial PO Box 700-65101 Vaasa Finland, 2016.

[2] Sun Tzu, The Art of War, translated and edited by R. Sawyer, New York, NY: Barnes and Noble, 1994.

[3] McCauley. Dan, "Strategic Thinking: Providing the Competitive Edge", SMALL WARS Journal, BY-NCSA 3.0, 2012.

[4] Ridgley, Stanley K, Strategic Thinking Skills, THE GREAT COURSES, Corporate Headquarters 4840 West fields Boulevard, Suite 500 Chantilly, Virginia, USA, 2012.

[5] Richter. Andrew, "THE EVOLUTION AND DEVELOPMENT OF STRATEGIC THINKING AT THE CANADIAN DEPARTMENT OF NATIONAL DEFENCE, 1B O- 1963", thesis Doctor of Philosophy, Graduate Programmed in Political Science York University Toronto, Ontario, Canada, 1998. 


\section{International Journal of Science and Research (IJSR) \\ ISSN (Online): 2319-7064}

Index Copernicus Value (2015): 78.96 | Impact Factor (2015): 6.391

[6] Sloan. Julia, LEARNING TO THINK STRATEGICALLY, Linacre House, ButterworthHeinemann, Burlington, MA 01803, USA, 2006.

[7] El Namaki M. S. S., Strategic Thinking for Turbulent Times, Palgrave Macmillan, Typeset by Palgrave Macmillan (MPS) Limited, Chennai, India, 2014.

[8] Braunstein. Daniel N., " Behavioral Science: Beyond Leavitt's "Narrow" Analytic Manager", Journal Informs pubsonline, Vol. 4, No. 4 (Aug., 1974), pp. 28-31, 1974.

[9] Stamp. G., "Management Styles", Leadership \& Organization Development Journal, Vol. 7 Iss 3 pp. 27 $-32,1986$.

[10] Wales. John, ” A Four-Culture Model of Collaborative Learning and Problem Solving", Management International Review, Vol. 20, No. 4, pp. 100-111, 1980.

[11] Jaques. Elliott, "General Theory of Bureaucracy", Journal of Social Policy, Vol: 7, Issue: 04, pp 500 $502,1976$.

[12] Stamp. G.,'LEVELS AND TYPES OF MANAGERIAL CAPABILITY", Journal of Management Studies, Vol. 18, Issn 3 pp. 277, 1981.

[13] Slocum. John W., and Hellriegel. Don, "A Look at How Managers' Minds Work", Journal Business Horizons, Vol:26, Iss:4, pp:0-68, 1983.

[14] Harvey. O. J., and Hunt. David. E., M. Harold, "Conceptual Systems and Personality Organization", psychosomatics journal impact factor, Taylor \& Francis Group, Vol. 10, No. 2, p. 144, 1971.

[15] Isaac. D.J., and O'Connor. B.M, "Experimental Treatment of a Discontinuity Theory of Psychological Development", Journal Human Relations, SAGE Social Science Collections, Vo: 22, N: 5 pp 427—455, 1969.

[16] Kinicki. Angelo, Fugate. Mel, "Organizational Behavior A Practical, Problem-Solving Approach", First edition, ISBN 978-1-259-18841-1, Published by McGraw-Hill Education, 2 Penn Plaza, New York, NY 10121, U.S.A, 2016.

[17] Robbins. Stephen P., and Judge. Timothy A., Organizational Behavior, 15 EDITION, Pearson Education Limited Edinburgh Gate Harlow Essex CM20 2JE, England, 2013.

[18] Robbins. Stephen P., and Judge. Timothy A., Essentials of Organizational Behavior, Twelfth Edition, Pearson Education, Inc, Permissions Department, One Lake Street, Upper Saddle River, New Jersey 07458, USA, 2014.

[19] Barling. Julian, and Cooper. Cary L., Organizational Behavior Volume I Micro Approaches, SAGE Publications Inc. 2455 Teller Road Thousand Oaks, California 91320, USA, 2008.

[20] George. Jennifer M., and Jones. Gareth R., Understanding and Managing Organizational Behavior, SIXTH EDITION, ISBN 10: 0-13-6124437, ISBN 13: 978-0-13-612443-6, Prentice Hall, One Lake Street, Upper Saddle River, New Jersey 07458, USA, 2012.

[21] Tjosvold. Dean, "Effects of crisis orientation on managers' approach to controversy in decision making", The Academy of Management Journal, Vol: 27, Issu:1, pp: 130-138, 1984.

[22] Champoux. Joseph E., ORGANIZATIONAL BEHAVIOR: INTEGRATING INDIVIDUALS, GROUPS, AND ORGANIZATION, Routledge is an imprint of the Taylor \& Francis Group, 270 Madison Avenue, New York, N Y 10016, USA, 2011.

[23] Hellriegel. Don, Slocum. John. W., Woodman. Richard. W., "Organizational Behavior", Fifth Edition, West Publishing Company, new York, USA, 1989.

[24] Schermerhorn. John R., Hunt. James G., and Osborn. Richard N., Organizational Behavior, Seventh Edition, John Wiley \& Sons, Inc, ISBN 0-471-22819-2, Printed in the USA, 2002.

[25]Run. Leslie W. and Byars. Lloyd L., Supervision Key Link to Productivity, Eighth Edition, McGrawHill Companies, Inc., 1221 Avenue of the New York, NY, 10020, USA, 2004.

[26] Al.marshad. Mohammad, " Strategic Thinking in Jordanian Publicly Quoted Companies", Doctoral thesis, University of Huddersfield, Queensgate, Huddersfield HD1 3DH, United kingdom, 2013.

\section{Author Profile}

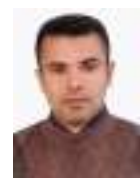

Ahmed Quinn Dawood, received a Bachelor's degree of Science in Public Administration in (2006) from college at Administration and Economics, University at Baghdad, then continued her studies at the same university for acquiring the master degree in Public Administration and specialization in Strategic management.

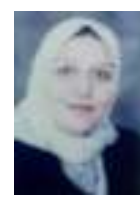

Dr. Suhair Adil AL- Jader, a university lecturer at college at Administration and Economics, University at Baghdad, is a specialist in the field at strategic and organizational management and a member in the scientific committee at the department at public Administration. 